\title{
Relationship among productive and economic variables of beef cattle in Brazil
}

\author{
Rogério Semchechem $^{1}$ (D) Simone Fernanda Nedel Pértile ${ }^{1^{*}}$ (D) Sandra Maria Simonelli ${ }^{2}$ iD \\ Maria Eugênia Andrighetto Canozzi ${ }^{3}$ Luiz Fernando Coelho da Cunha Filho ${ }^{1}$ iD \\ Mateus Ludovico Zamboti ${ }^{1}$ Marilice Zundt ${ }^{4}$ Marcelo Diniz dos Santos ${ }^{5}$ iD \\ Antonio Chaker El Memari Neto ${ }^{6}$ (D) Fabiola Cristine de Almeida Rego ${ }^{1}$ (D)
}

\author{
${ }^{1}$ Universidade Norte do Paraná (UNOPAR), 86702-670, Arapongas, PR, Brasil. E-mail: s.pertile@zootecnista.com.br. "Corresponding author. \\ ${ }^{2}$ Universidade Estadual de Londrina (UEL), Londrina, PR, Brasil. \\ ${ }^{3}$ Instituto Nacional de Investigación Agropecuaria (INIA), Programa Producción de Carne y Lana, Estación Experimental INIA La Estanzuela, \\ Colonia, Uruguay. \\ ${ }^{4}$ Universidade do Oeste Paulista (UNOESTE), Presidente Prudente, SP, Brasil. \\ ${ }^{5}$ Universidade de Cuiabá (UNIC), Cuiabá, MT, Brasil. \\ ${ }^{6}$ Instituto de Métricas Agropecuárias (Inttegra), Maringá, PR, Brasil.
}

ABSTRACT: The present study aimed to obtain, through statistical methods, the independent variables that influence the economic and productive results of Brazilian beef cattle. Economic and productive information was collected from 106 farms in Brazil. Data collection was performed by the Instituto de Métricas Agropecuárias (Inttegra). The variable selection method used was stepwise regression followed by polynomial regression analyses. The variable beef cattle economic result showed the positive effect of disbursement per head per month and average weight gain. An average daily gain of $520 \mathrm{~g}$ in live weight was obtained, and this variable was influenced especially by nutrition cost. The arroba production (arroba is a unit of weight corresponding to $15 \mathrm{~kg}$ ) was influenced by the linear effect of nutrition cost and stocking rate. The variable arroba production in pasture showed a linear and positive effect of average weight gain in pasture and stocking rate in pasture. For profit per arroba, the variables nutrition cost, disbursement with pasture, and average sale price had a linear effect. The independent variables that had the greatest influence on the response variables were stocking rate, average daily weight gain, and nutrition cost. Thus, increases in investment in nutrition and stocking rate should result in higher production rates and improvements in the profitability of this activity.

Key words: nutrition costing, average daily gain, profit, management, stocking rate.

Relações entre variáveis produtivas e econômicas de bovinocultura de corte no Brasil

RESUMO: O presente trabalho teve como objetivo obter, por meio de métodos estatísticos, quais variáveis independentes influenciam as variáveis econômicas e produtivas na bovinocultura de corte brasileira. O banco de dados utilizado foi obtido por coleta de informações econômicas e produtivas em 106 fazendas no Brasil. O método de coleta de dados foi definido pelo Instituto de Métricas Agropecuárias (Inttegra). Foram realizadas análises de seleção de variáveis pelo método Stepwise, seguido por análises de regressão múltipla. A variável resultado econômico da bovinocultura de corte teve efeito positivo do desembolso mensal por cabeça e do ganho de peso médio diário. Para o ganho de peso médio diário foi obtido um valor médio de 520 gramas, e esta variável foi influenciada principalmente pelo custeio com nutrição. Para a produção de arroba foi obtido efeito linear do custeio com nutrição e da taxa de lotação. Para a variável produção de arroba a pasto foi obtido um efeito linear e positivo do ganho médio diário de peso no pasto e da taxa de lotação no pasto. Para o lucro por arroba, as variáveis custeio com nutrição, desembolso com pastagem e preço médio de venda tiveram efeito linear. As variáveis independentes que tiveram maior influência nas variáveis resposta foram a taxa de lotação, o ganho médio diário de peso e o custeio com nutrição. Assim, aumentos no investimento em nutrição e na taxa de lotação dos animais devem resultar em maiores índices de produção e em melhorias na rentabilidade da atividade.

Palavras-chave: custo nutricional, ganho médio diário, lucro, gestão, taxa de lotação.

\section{INTRODUCTION}

Food production is an extremely important economic factor for the world's population as it is closely linked to the basic needs of the population. Thus, the beef production chain is very important for the economy, especially in Brazil, where agribusiness contributes significantly to the gross domestic product, and was $21.6 \%$ in 2017 (CEPEA, 2018). Investments in the cattle production chain increase daily, which leads to improvements in the structure of this chain and makes the activity more professional, increasing profitability (LUCHIARI FILHO, 2000). 
Production systems in beef cattle are generally managed without any systematic processes, which makes it difficult to assess the production costs; and consequently, affect decision making. According to OAIGEN et al. (2008), in a beef cattle farm, there should be an incentive to implement business management concepts based on the knowledge of strategic information.

The profitability of beef cattle activity is a factor that depends on different variables, and each has a degree of importance in determining profit or loss. Thus, knowing the importance of these variables can be a crucial point in knowing where to strategically determine changes in management to improve profitability.

The knowledge of production costs is very important to conduct a profitability analysis of farms (DEMEU et al. 2013), and the farmer will know in detail the factors of production such as land, labor, and capital. Moreover, according to these authors, with the knowledge of economic variables, it is possible to more easily and accurately diagnose bottlenecks, which allows us to concentrate on managerial and technological inputs, thus presenting greater possibilities of achieving the goals and success in the activity.

Owing to the economic and social importance of beef cattle and the pressure for greater precision to provide improvements in the economic and productive indexes of this activity, the aim of this study was to identify which variables most influence the productive and economic traits, and to determine the relationship between these economic and productive variables.

\section{MATERIALS AND METHODS}

The data set comprised information from 106 beef cattle farms located in different regions of Brazil: South $(\mathrm{n}=13)$, Southeast $(\mathrm{n}=11)$, Northeast $(\mathrm{n}=7)$, North $(\mathrm{n}=17)$, and Midwest ( $=58$ ), collected from July 2017 to June 2018. The states by region were as follows: North (Tocantins, Rondônia, and Para), Northeast (Bahia, Maranhão, and Rio Grande do Norte), Midwest (Mato Grosso, Mato Grosso do Sul, and Goiás), Southeast (Espírito Santo and São Paulo), and South (Paraná and Rio Grande do Sul). The properties studied had weaning and finishing system, and 55 farms were with and 51 without feedlots. Data collection was designed, performed, and standardized by the Instituto de Métricas Agropecuárias (Inttegra), located in Maringá, Paraná, Brazil. The variables studied were classified into three groups: farm characterization, economic, and productive.

The farm characterization variables were pasture area (PAREA), defined as the size of pasture area in hectares for livestock; herd size (HS), defined by the number of animals raised on the properties during the data collection period; pasture stocking rate (PSR), which is the number of animal units reared in one hectare, calculated as the number of animal units divided by the area under grazing livestock; and stocking rate (SR), which is the number of animal units reared in one hectare, calculated as the number of animal units divided by the area intended for animal production. An animal unit (AU) represents $450 \mathrm{~kg}$ of body weight of an animal.

The beef cattle economic result (BCER), measured in dollars per hectare, was obtained by the difference between all expenses and revenue in beef cattle divided by the area in hectares used for this activity. Thus, this variable indicated beef cattle activity profitability by hectare. Profit by animal arroba produced (PA), measured in dollars, was obtained by average sale price per produced arroba less total cost per arroba produced, and indicates the net profit per animal arroba produced. Profit margin on sale (PMS), measured in dollars, was calculated by dividing PA by the average sale price per produced arroba. Average selling price (AVSP) was the average, in dollars, of the sale price of an arroba. In Brazil, the arroba is a common weight measure that equals approximately $15 \mathrm{~kg}$.

The cost of arroba produced (CAP) is a dollar amount that represents the total cost to produce an arroba. Herd inputs (HI), expressed in dollars were obtained from the sum of all expenditures on nutrition, health, reproduction, and pasture per animal over a period of one month. Nutrition cost (NUTC) is a dollar amount that represents the amount spent on nutrition per animal over a one-month period and does not involve labor costs or maintenance of feeders. Pasture disbursement (PASTD) can be defined as a dollar amount that expresses how much was spent on pasture per animal over a period of one month. Disbursement per head per month (DHM) was the amount in dollars spent on one animal over a one-month period on nutrition, breeding, health, permanent labor, management, machine park (cost and investment), pasture (cost and investment), infrastructure (cost and investment), fees, and taxes.

The average daily weight gain (ADG), measured in $\mathrm{kg}$, was obtained by dividing the total weight gain of an animal by the days on which this animal was evaluated. Pasture average daily weight 
gain (PADG) was measured in $\mathrm{kg}$ and was obtained using the same calculation as that used for the ADG, but only for animals raised in the pasture production system.

Arroba production (APROD) was defined as the number of arrobas produced in one hectare per year, accounting for all production systems, and was obtained by dividing the total number of arrobas produced by each farm by the area used for animal production on the farm. In addition, pasture arroba production (PAPROD) was obtained by dividing the total amount of arrobas produced on pasture on the farm by the area used for pasture animal production on the farm.

The response variables studied were ADG, APROD, PAPROD, PA, and BCER. First, Pearson correlations between the response variables and independent variables were calculated. For each response variable, the selected independent variables were chosen as fixed effects when the correlation coefficient between them and the response variables was greater than 0.25 . In addition, when the correlation coefficient between the independent variables was greater than 0.70 , the choice of the independent variable that remained in the model was obtained according to their biological and/or economic importance. A variable selection analysis was performed using the stepwise method, whereby models were compared considering one complete model and one without a linear predictor. The best model was selected considering the Akaike information criterion (AKAIKE, 1974). Linear and quadratic effects were studied in polynomial regression analysis. The assumptions of regression analysis of normality and homogeneity of variance were assessed using the Shapiro-Wilk test and scatter plots, respectively, and when necessary, outliers were removed. The proportion of explained variance (VE) for each independent variable in relation to the response variable was calculated by dividing the sum of squares of each variable in relation to the total sum of squares. All statistical analyses were performed using the R statistical software (R Core Team, 2019), and the significance level was set at 0.05 .

\section{RESULTS AND DISCUSSION}

For the economic variable BCER, the descriptive statistics obtained indicated a large variation in economic return among the farms studied, which varied from a profit of US\$ 388.39 ha per year to a loss of US\$ 1110.95 ha per year (Table 1). Nevertheless, among all farms studied, 77 were profitable and 29 showed losses in beef cattle production. These variables exemplify the great variability in yields generated by beef cattle in Brazil. Moreover, these results indicated that some farmers may be using their patrimony to fund this activity; and will possibly no longer continue if there are no changes, such as the professionalization of the activity (LUCHIARI FILHO, 2000). Although, most farms studied were profitable, the profit can be much lower than necessary to generate a proper remuneration for cattle farmers (CANOZZI et al. 2019).

The descriptive statistics obtained for productive variables showed the large variation in the farms studied in relation to the pasture area, which ranged from 25 to 40000 ha, and the number of beef cattle per farm, which ranged from 127 to 47000 animals (Table 2). The production system (with or without of feedlot) of beef cattle and the region in which the farm is located were not as relevant in the analysis as economic and productive variables; therefore, they were only used to describe the data. Regarding the size of the properties and the pasture area, the properties allocated in the South had smaller pasture areas (25 to 536 hectares), whereas those in the North had the largest extensions of pasture areas (441 to 33.217 hectares). According to SAATH \& FACHINELLO (2018), with the growing demand for food in Brazil because of population growth, and to meet the increasing demand for agricultural products in Brazil until the year 2024, it is necessary to expand productivity and planted areas. However, the expansion of the agricultural frontier is quite restricted.

The values obtained for ADG ranged from 150 to $940 \mathrm{~g} \mathrm{~d}^{-1}$, with an average of $520 \mathrm{~g} \mathrm{~d}^{-1}$. For PADG, the average value obtained was $460 \mathrm{~g}$ $\mathrm{d}^{-1}$. These variables are also indicative of the large difference between the farms studied; however, the variation in weight gain was approximately four times lower than that of the variables indicating size of the property, such as herd size. The ADG, either in feedlots or pastures, is influenced by many factors; however, the biggest differences occur owing to changes in nutritional management. FISCHER et al. (2005), in a study to evaluate the effects of different amounts of energy supplementation on animals raised on native pastures in Rio Grande do Sul, obtained ADG values between 360 and $760 \mathrm{~g} \mathrm{~d}^{-1}$.

A linear effect between ADG and nutrition cost was observed (Table 3), consistent with the findings of FISCHER et al. (2005), who showed a linear and positive effect of energy supplementation on ADG. In addition, MARCONDES et al. (2011) concluded that the animals that received the largest 
Table 1 - Number of farms evaluated $(\mathrm{N})$, mean, standard deviation (SD), minimum (MIN) and maximum (MAX) values for the economic variables of 106 beef cattle farms in Brazil.

\begin{tabular}{|c|c|c|c|c|c|}
\hline Variables ${ }^{*}$ & $\mathrm{~N}$ & Mean & SD & MIN & MAX \\
\hline BCER(US\$ ha ${ }^{-1}$ ) & 76 & 31.27 & 203.12 & -1110.95 & 388.39 \\
\hline PA(US\$ per@) & 104 & 7.19 & 15.40 & -49.04 & 31.04 \\
\hline PMS (US\$ per@) & 104 & 0.05 & 0.11 & -0.34 & 0.22 \\
\hline AVSP (US\$ per@) & 105 & 41.16 & 3.41 & 36.05 & 61.64 \\
\hline DHM(US\$ per animal per month) & 104 & 20.44 & 12.69 & 5.40 & 62.00 \\
\hline CAP(US\$ per@) & 103 & 34.13 & 15.67 & 12.12 & 91.80 \\
\hline HI (US\$ per herd) & 85 & 8.22 & 6.82 & 0.65 & 35.26 \\
\hline NUTC(US\$ per animal per month) & 85 & 7.27 & 6.30 & 0.34 & 31.86 \\
\hline PASTD(US\$ per animal per month) & 98 & 2.07 & 1.57 & 0.01 & 6.00 \\
\hline
\end{tabular}

*BCER: beef cattle economic result; PA: profit by animal arroba, PMS: profit margin on sale; AVSP: average selling price; DHM: disbursement per animal per month; CAP: cost by arroba produced; HI: herd inputs; NUTC: nutrition cost; PASTD: pasture disbursement.

amount of concentrate presented higher performance in weight gain.

For APROD, the variables nutrition cost, stocking rate and BCER had a positive linear effect. However, most of the APROD variation was explained by nutrition cost and stocking rate, with 57.33 and $35.95 \%$ of variation, respectively, while BCER explained only $0.47 \%$. A coefficient of 0.519 was obtained for the cost of nutrition, i.e., for each dollar used for the cost of nutrition, an increase of 0.519 was expected in the arrobas produced, which is equivalent to $7.77 \mathrm{~kg}$ of body weight per animal per hectare. For the stocking rate, the increase of one animal unit per hectare could increase arrobas produced per hectare by 9.69. Thus, if an increase in arrobas production occurs, the profitability of the activity will improve, accompanied by an efficient nutrition cost and a high stocking rate.

For the PAPROD variable, the results indicated a positive linear effect for stocking rate and for PADG. For the stocking rate, which explained $73.36 \%$ of the PAPROD variation, the increase of

Table 2 - Number of farms evaluated $(\mathrm{N})$, mean, standard deviation (SD), minimum (MIN) and maximum (MAX) values for the production variables of 106 beef cattle farms in Brazil.

\begin{tabular}{|c|c|c|c|c|c|}
\hline Variables $^{*}$ & $\mathrm{~N}$ & Mean & SD & MIN & MAX \\
\hline PAREA (ha) & 106 & 2627.15 & 4366.02 & 25.00 & 33217,91 \\
\hline HS & 106 & 3773.50 & 5999.66 & 127.00 & 47766.00 \\
\hline $\mathrm{SR}\left(\mathrm{AU} \mathrm{ha}^{-1}\right)$ & 104 & 1.48 & 0.95 & 0.31 & 5.61 \\
\hline $\operatorname{PSR}\left(\mathrm{AU} \mathrm{ha}^{-1}\right)$ & 86 & 1.27 & 0.70 & 0.31 & 4.63 \\
\hline $\operatorname{ADG}\left(\mathrm{Kg} \mathrm{d}^{-1}\right)$ & 100 & 0.52 & 0.18 & 0.15 & 0.94 \\
\hline $\operatorname{PADG}\left(\mathrm{Kg} \mathrm{d}^{-1}\right)$ & 81 & 0.46 & 0.14 & 0.13 & 0.83 \\
\hline APROD (@ ha-1 per year) & 103 & 14.98 & 12.90 & 0.93 & 61.06 \\
\hline PAPROD (@ ha-1 per year) & 83 & 10.54 & 7.47 & 0.93 & 42.95 \\
\hline
\end{tabular}

"PAREA: pasture area; HS: herd size; SR: stocking rate; PSR: pasture stocking rate; ADG: average daily weight gain; PADG: pasture average daily weight gain; APROD: arroba production; PAPROD: pasture arroba production.

Ciência Rural, v.51, n.4, 2021. 
Table 3 - Regression analysis for variables ADG, APROD, PAPROD, PA and BCER of 106 beef cattle farms in Brazil.

\begin{tabular}{|c|c|c|c|c|c|c|}
\hline Response variables ${ }^{*}$ & Independent variables & ----------- & ----------------' & VE $(\%)$ & SEM & $\mathrm{R}^{2}$ \\
\hline & & Linear & Quadratic & & & \\
\hline $\mathrm{ADG}^{1}$ & NUTC & 0.0001 & 0.1283 & 45.00 & 0.0129 & 0.45 \\
\hline \multirow{3}{*}{$\mathrm{APROD}^{2}$} & NUTC & 0.0001 & 0.7625 & 57.33 & 0.3178 & 0.94 \\
\hline & BCER & 0.0311 & 0.3793 & 0.47 & & \\
\hline & $\mathrm{SR}$ & 0.0001 & 0.7528 & 35.95 & & \\
\hline \multirow{2}{*}{ PAPROD $^{3}$} & PSR & 0.0001 & 0.6157 & 73.36 & 0.2093 & 0.95 \\
\hline & PADG & 0.0001 & 0.3532 & 21.27 & & \\
\hline \multirow{3}{*}{$\mathrm{PA}^{4}$} & NUTC & 0.0001 & 0.4770 & 20.52 & 0.8389 & 0.37 \\
\hline & PASTD & 0.0001 & 0.5278 & 11.71 & & \\
\hline & AVSP & 0.0122 & 0.4617 & 5.02 & & \\
\hline \multirow{2}{*}{$\mathrm{BCER}^{5}$} & DHM & 0.0001 & 0.5093 & 26.41 & 5.8696 & 0.78 \\
\hline & $\mathrm{ADG}$ & 0.0001 & 0.2166 & 51.95 & & \\
\hline
\end{tabular}

*SEM: standard error of the mean; $\mathrm{R}^{2}$ : coefficient of determination; BCER: beef cattle economic result; PA: profit by animal arroba, AVSP: average selling price; DHM: disbursement per head per month; NUTC: nutrition costing; PASTD: pasture disbursement; SR: stocking rate; PSR: pasture stocking rate; ADG: average daily weight gain; PADG: pasture average daily weight gain; APROD: arroba Production; PAPROD: pasture arroba production; VE: variance explained.

${ }^{1}$ Regression equation: $0.389+0.015 \mathrm{x}_{1}$, in which $\mathrm{x}_{1}$ is the NUTC variable;

${ }^{2}$ Regression equation: $-4.3307+0.519 \mathrm{x}_{1}+0.006 \mathrm{x}_{2}+9.6909 \mathrm{x}_{3}$, in which $\mathrm{x}_{1}, \mathrm{x}_{2}$ and $\mathrm{x}_{3}$ are NUTC, BCER and SR variables, respectively;

${ }^{3}$ Regression equation: $-8.3213+8.8036 \mathrm{x}_{1}+16.3955 \mathrm{x}_{2}$, in which $\mathrm{x}_{1}$ and $\mathrm{x}_{2}$ are PSR and PADG variables, respectively;

${ }^{4}$ Regression equation: $-2.10-0.56 \mathrm{x}_{1}-1.97 \mathrm{x}_{2}+0.54 \mathrm{x}_{3}$, in which $\mathrm{x}_{1}, \mathrm{x}_{2}$ and $\mathrm{x}_{3}$ are NUTC, PASTD and AVSP variables, respectively;

${ }^{5}$ Regression equation:-54.27-13.93 $\mathrm{x}_{1}+698.34 \mathrm{x}_{2}$, in which $\mathrm{x}_{1}$ and $\mathrm{x}_{2}$ are DHM and ADG variables, respectively.

one animal unit per hectare of pasture could lead to an increase in production by 8.8036 arrobas per hectare of pasture per year. For ADG in pasture, the increment of $1 \mathrm{~kg}$ of ADG per pasture could result in an increase of 16.3955 arrobas per hectare per year in pasture productivity, and thus, every $100 \mathrm{~g}$ of ADG per pasture could obtain 1.93 additional arrobas produced per hectare of pasture per year.

REIS et al. (2009), in a study on the influence of diet supplementation in beef cattle as a strategy for pasture management, obtained results indicating that supplementation of grazing animals may allow increased stocking rate and weight gain in the area. Nevertheless, the average stocking rate obtained in this study was $1.48 \mathrm{AU} \mathrm{ha}^{-1}$, and thus, care should be taken with the use of high stocking rates, especially in native and unimproved pasture areas because it can negatively affect farms with low bioeconomic efficiency (MARQUES et al., 2011).

For the PA variable, a significant linear effect was obtained for nutrition and pasture expenditure, which explained 20.52 and $11.71 \%$ of PA variation, respectively. These results indicated that a correct expenditure on nutrition and pasture can lead to a higher profit per arroba produced similar to that observed with the other variables. For average selling price, a significant linear effect was also observed, and thus, selling the animal for a high added value may mean that the profit per arroba will increase. OAIGEN et al. (2013) ranked sale price determination as one of the critical factors in beef cattle farm competitiveness, along with other factors such as crop-livestock integration, strategic planning, calculation of financial indicators, access to technological innovations, and organization of the farmers.

For BCER, the independent variables disbursement per head per month and ADG showed significant linear effects, which explained 26.41 and $51.95 \%$, respectively, of the BCER variability. According to the linear regression, an increase in one disbursement dollar per head per month could decrease BCER by US\$ 13.93 in a year. In addition, increasing ADG by $1 \mathrm{~kg}$ may result in an increase of US\$ 698.34 in BCER. This highlighted the importance 
of being extremely efficient, increasing earnings, and controlling disbursement. These results indicate that disbursements for nutrition, pasture, and health positively and directly influence the profitability of the farms. In addition, this disbursement is a means of improving animal weight gain, for which a linear effect on the BCER variable was also obtained.

According to CANOZZI et al. (2019), who evaluated the level of bioeconomic efficiency of cattle farmers in the western frontier region of the state of Rio Grande do Sul, Brazil, through typology, the main differences among the farms are because of the use of technologies related to feeding and cost management. Nevertheless, these authors reported that in farms with high bioeconomic efficiency, investments to increase productivity, especially in nutrition, do not always ensure better economic results. Thus, an economic evaluation is necessary before implementing a new technology.

The PA and BCER variables were influenced by nutrition and pasture expenditure. An economic feasibility analysis between two beef cattle production systems classified as extensive (lower disbursement) and semi-intensive full cycle was performed by NASCIMENTO et al. (2017), and the values obtained for net margin per hectare were $\mathrm{R} \$$ 582.26 for the extensive system and $\mathrm{R} \$ 993.99$ for the semi-intensive system. Thus, the extensive system was considered less viable.

However, the profit from grazing cattle production varies greatly according to the forage used and its management. SOARES et al. (2015), studying the profitability of finishing beef cattle on irrigated pastures, obtained a profit of $\mathrm{R} \$-583.18$, 291.61, and -28.99 per hectare for different pasture systems. They concluded that pasture irrigation for termination of beef cattle is economically viable; however, this system should be used considering animal productivity owing to its high cost.

Analyzing commercial fed steers and heifers in the United States, TATUM et al. (2012) reported that carcass-based G:F, obtained from the relationship between carcass weight gain $(G)$ and the average amount of food ingested by the animal (F), was the most important contributor to differences in net return per animal, which is consistent with the results obtained in the present study.

\section{CONCLUSION}

The cost of nutrition, stocking rate, and average daily weight gain alters the system's profitability. It is also concluded that investments in beef cattle raising increased the performance and profit of farms.

\section{ACKNOWLEDGMENTS}

The authors are grateful to the Instituto de Métricas Agropecuárias (Inttegra), for providing the data set and support in this research; and for the Coordenação de Aperfeiçoamento de Pessoal de Nível Superior (CAPES), for financed in part this study (Finance code 001), and for the post-doctoral scholarship of the second author

\section{DECLARATION OF CONFLICTS OF INTERESTS}

The authors declare no conflict of interest. The founding sponsors had no role in the design of the study; in the manuscript, and in the decision to publish the results.

\section{AUTHORS' CONTRIBUTIONS}

All authors contributed equally for the conception and writing of the manuscript. All authors critically revised the manuscript and approved of the final version.

\section{REFERENCES}

AKAIKE, H. A new look at the statistical model identification. IEEE transactions on automatic control, v.19, p.716-723, 1974. Available from: <https://ieeexplore.ieee.org/stamp/stamp. jsp?tp $=$ \&arnumber $=1100705>$. Accessed: Jul. 24, 2020. doi: 10.1109/TAC.1974.1100705.

CANOZZI, M.E.A. et al. Typology of beef production systems according to bioeconomic efficiency in the south of Brazil. Ciência Rural, v.49, 2019. Available from: <http://dx.doi. org/10.1590/0103-8478cr20190030>. Accessed: Oct. 16, 2019. doi: $10.1590 / 0103-8478 \mathrm{cr} 20190030$.

CEPEA - Centro de Estudos Avançados em Economia Aplicada. PIB do agronegócio brasileiro. 2019. Available from: <https:// www.cepea.esalq.usp.br/br/pib-do-agronegocio-brasileiro.aspx $>$. Accessed: Jan. 13, 2019.

DEMEU, A.A. et al. Production scale effect on the profitability of beef cattle in a pasture system in the South of Minas Gerais State. Archivos Latinoamericanos de Producción Animal, v.21, p.97106, 2013. Available from: <https://pdfs.semanticscholar.org/9ced/ 414e83b97dad9bc31a7e0eb6e5716c445e5a.pdf>. Accessed: Jul. 24, 2020.

FISCHER, V. et al. Increasing levels of energy supplementation on weight gain of grazing steers kept on a natural pasture at the southeastern region of Rio Grande do Sul. Revista Brasileira de Zootecnia, v.34, p.159-166, 2005. Available from: <http://dx.doi. org/10.1590/S1516-35982005000100020>. Accessed: Sep. 03, 2019. doi: $10.1590 / \mathrm{S} 1516-35982005000100020$.

LUCHIARI FILHO, A. Pecuária da carne bovina. São Paulo, 2000, 134 p.

MARCONDES, M.I. et al. Feed efficiency of pure and cross bred cattles fed high or low concentrate level. Revista Brasileira de Zootecnia, v.40, p.1313-1324, 2011. Available from: <http:// dx.doi.org/10.1590/S1516-35982011000600021>. Accessed: Sep. 03, 2019. doi: 10.1590/S1516-35982011000600021. 
MARQUES, P.R. et al. Competitiveness of beef farming in Rio Grande do Sul State, Brazil. Agricultural Systems, v.104, p.689-693, 2011. Available from: <https://doi.org/10.1016/j. agsy.2011.08.002>. Accessed: Oct. 25, 2019. doi: 10.1016/j. agsy.2011.08.002.

NASCIMENTO, M.F.A. et al. Economical viability of two systems of beef cattle production. Espacios, v.38, p.10, 2017. Available from: <http:/www.revistaespacios.com/a17v38n27/ a17v38n27p10.pdf>. Accessed: Oct. 24, 2019.

OAIGEN, R.P. et al. Organizational improvement in the beef calves production from of the cost centers. Revista Brasileira de Zootecnia, v.37, p.580-587, 2008. Available from: <http://dx.doi. org/10.1590/S1516-35982008000300025>. Accessed: Aug. 03, 2019. doi: 10.1590/S1516-35982008000300025.

OAIGEN, R.P. et al. Beef cattle production system competitiveness in the south of Brazil. Archivos de Zootecnia, v.62, p.161170. 2013. Available from: <http://dx.doi.org/10.4321/S000405922013000200001>. Accessed: Oct. 24, 2019. doi: 10.4321/ S0004-05922013000200001.

R Core Team (2019). R: A language and environment for statistical computing. R Foundation for Statistical Computing, Vienna Austria. URL https://www.R-project.org/.
REIS, R.A. et al. Supplementation of beef cattle as strategy of pasture management. Revista Brasileira de Zootecnia, v. 38, p. 147-159, 2009. Available from: <http://dx.doi.org/10.1590/S151635982009001300016>. Accessed: Aug. 02, 2019. doi: 10.1590/ S1516-35982009001300016.

SAATH, K.C.O.; FACHINELLO, A.L. Crescimento da demanda mundial de alimentos e restrições do fator terra no Brasil. Revista de Economia e Sociologia Rural, v.56, p.195-212, 2018. Available from $<$ http://www.scielo.br/scielo.php?script=sci arttext\&pid $=$ S0103-20032018000200195 \&lng=en\&nrm=iso $>$. Acessed: Jul. 07, 2020. doi: 10.1590/1234-56781806-94790560201.

SOARES, J.C.R. et al. Economic evaluation of finishing beef cattle on irrigated pasture. Arquivo Brasileiro de Medicina Veterinária e Zootecnia, v.67, p.1096-1104, 2015. Available from: <http:// dx.doi.org/10.1590/1678-4162-7340>. Accessed: oct. 24, 2019. doi: $10.1590 / 1678-4162-7340$.

TATUM, J.D. et al. Carcass-based measures of cattle performance and feeding profitability. The Professional Animal Scientist, v.28, p.173-183, 2012. Available from: <https://doi.org/ 10.15232/ S1080-7446(15)30338-7>. Accessed: Aug. 20, 2019. doi: 10.15232/S1080-7446(15) 30338-7. 